\title{
Obituaries
}

Obituaries should be submitted by email to Ruth Doherty at r.doherty@nature.com.

All submitted obituaries should be 450 words maximum in length (apart from obituaries for past presidents of the BDA where the length should be 800 words).

Content of the obituary is down to the individual author, and the approval of the family should be given for the obituary prior to submission to the BDJ

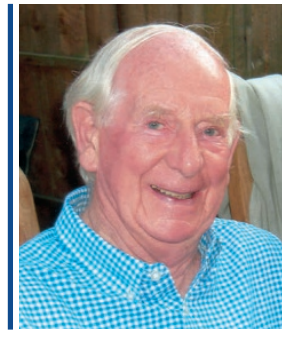

Peter Alan Long

1932-2016

Peter Long, who died on 3 August 2016, could be said to have had three careers in dentistry, each he thoroughly enjoyed.

After grammar school a Middlesex Scheme County Scholarship took him to Mill Hill, which had a medical sixth form. This vocational scheme, leading to his choice of dentistry at Guy's, was remarkable at the time.

An exciting and varied start for Peter came during National Service, when, in 1954 after his time as Resident Dental House Surgeon (on a salary of $£ 125$ a year), he was posted as an Officer in the Royal Army Dental Corps to the base hospital for Korea, in Japan. On the way he was expected to provide all necessary dental services on the troopship with a field kit and a foot-treadle drill (recalled as being excellent when powered by the orderly).

After leaving the army, marrying Judy, and starting his main career in practice in Hertford, Peter took a part-time post at Guy's under Frank Ingram in the dental X-Ray department.

The career which most suited his deep commitment to teaching came next at $\mathrm{UCH}$ as a part-time demonstrator in oral surgery, from 1961 until its closure.

Peter needed to deal with the high child caries rate in the Home Counties; he had such a calming influence on children that most hardly needed the $\mathrm{N}_{2} \mathrm{O}$, they were talked into analgesia.

The NHS was well suited to a man with his social conscience, and the Hertford practice flourished. The VT scheme extended Peter's teaching and mentoring activities, and he was an outstanding and caring tutor to those lucky enough to come under his guidance.
Towards retirement Peter took on the challenging role of adviser to fellow practitioners in the Dentist Support Scheme, where those with problems with the use of drugs or alcohol needed a guiding hand.

A keen Rotarian, Peter was awarded a Paul Harris Fellowship in recognition of his commitment to helping people in need.

Neither of his sons followed him into dentistry, so Peter was delighted when he acquired Dianne (Eggleton) as a daughter-inlaw, who had met his son while on the practice visit that he offered all his house surgeons.

Peter's reminiscences are recorded in the MacLean Interviews held at the BDA.

M. Bishop

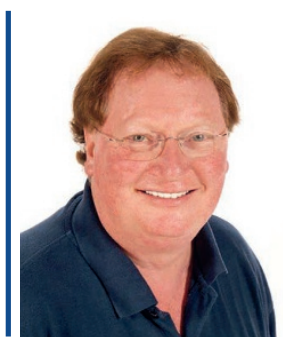

\section{Graham Gilmour}

1955-2016

Dr Andrew Graham Gilmour died peacefully on 8 January 2016 after a short illness, at the untimely age of 60 . Graham was born on Good Friday, 1955. He qualified at Glasgow Dental School in 1978, then joined the SHO/ Registrar rotation in Glasgow and passed the FDSRCPS in 1982. He became a lecturer in prosthodontics shortly afterwards and in 1988 was appointed consultant in restorative dentistry at Mayday Hospital, Croydon. A member of the appointments committee later told me that Graham was the most outstanding applicant for the post among the candidates.

Graham quickly developed the service in Croydon and established outreach clinics around the southeast of England, including Bournemouth, Portsmouth and Southampton, which soon attracted the attention of the dental teaching hospitals in London who wanted to get their higher trainees in restorative dentistry and orthodontics into attachments at Graham's unit in Croydon. Most of these trainees were later appointed consultants and professors up and down the UK.

Graham was particularly skilled as a diagnostic clinician, a first class teacher, an educator, who was invited to lecture locally, nationally and internationally, where his clinical skills and natural humour endeared him to every audience. He had a very sharp political touch. He understood how NHS committees worked and developed the philosophy that one should be either a committee member or chairman, but never the treasurer or secretary! He was appointed Associate Postgraduate Dental Dean for the KSS Region in 2003, and was asked to organise the training of clinical dental technicians which attracted applicants from all around the UK, every one of whom successfully completed the course and held Graham in the highest esteem.

One of his most endearing attributes was his unique sense of humour and fun, for which his trainees will testify. He organised educational programmes with the Cunard shipping line, crossing the Atlantic to New York on the QE2 twice, and cruising with Cunard in the Caribbean in 1994 which proved to be very popular. He had a particularly mischievous sense of humour; in 1982 Pope John Paul II came to Glasgow to say mass. On the same day, in Glasgow Dental Hospital, the oral surgery registrar received a phone call from a Cardinal, who was the Pope's personal secretary, reporting that the Holy Father had toothache and wanted to see the Professor of Oral Surgery, at $4 \mathrm{pm}$ that day! It was of course, a joke, played by 'Cardinal' Graham Gilmour!

Graham was hugely loved by his colleagues at Mayday Hospital in Croydon, and will be sadly missed by all of those who worked with him, his brother Rowland, but most of all by his wife Virginia, and his daughters Ginny and Ally.

M. Cassidy 